DARIUSZ SZENKOWSKI

Wydział Prawa i Administracji UJ

\title{
Pluralizm wartości a wola i racjonalność ustawodawcy - konflikt aksjologiczny w systemie i stosowaniu prawa
}

\section{Wstęp: Polityka wartości}

Nie istnieją rozwinięte demokratycznie społeczeństwa (narody), w których istniałby jeden system aksjologiczny (albo normatywny). Pluralizm aksjologiczny jest immanentną cechą demokratycznego, współczesnego społeczeństwa, w którym system prawny, tworząc porządek prawny, opiera się na sformalizowanych, zhierarchizowanych i zinstytucjonalizowanych normach prawnych ${ }^{1}$ urzeczywistniających $\mathrm{w}$ mniejszym lub większym wymiarze uniwersalne wartości postulowane także przez inne systemy normatywne. Z kolei pluralizm moralny w państwie (moralność pozytywna, etyka świecka, katolicka, protestancka, buddyjska czy w końcu - normy autonomiczne człowieka) implikuje nam dyferencjację aksjologiczną wartości postulowanych przez system prawny i wartości preferowanych przez społeczeństwo, które jest adresatem norm prawnych, ustanowionych jednak

W pozytywizmie instytucjonalnym (MacCormick, Weinberger) przyjmuje się, że akty stosowania prawa nie są rezultatem prostych operacji logicznych, a podmiot stosujący prawo zawsze wnosi do tych aktów pewien element twórczy, tj. preferowany przez siebie system wartości, zob. Zarys teorii państwa i prawa, red. A. Redelbach, S. Wronkowska, Z. Ziembiński, Warszawa 1994, s. 104. 
przez mniejszość (nadawca - prawodawca, czyli „mniejszość”, a adresaci norm, czyli większość - zróżnicowane społeczeństwo) ${ }^{2}$.

Teoretyczny model demokratycznego tworzenia prawa zakłada, że naród sprawuje władzę przez swoich przedstawicieli (lub bezpośrednio), którzy - wybierani w wyborach do sejmu czy senatu - stanowią władzę ustawodawczą tworzącą prawo o określonych wartościach. Doświadczenie pokazuje, że życie polityczne to z reguły mnogość partii politycznych, które mogą różnić się swoimi programami wyborczymi. Ścieranie się różnych sił utrudnia osiągnięcie konsensusu w niektórych kluczowych kwestiach (np. sprawa uwłaszczenia, prywatyzacja strategicznych gałęzi przemysłu, propozycja odpłatności za szkolnictwo wyższe, minimalizowanie nierówności społecznych, aborcja itp.) i powoduje, że przy braku większości parlamentarnej tworzona jest koalicja ugrupowań politycznych, której głównym celem jest „utrzymanie" rządu i forsowanie swojej polityki, czyli określonej wizji rozwiązań prawych i funkcjonowania państwa. Często też w takiej sytuacji raczej nie liczą się już obietnice wyborcze danej koalicji, która skoncentrowana jest przede wszystkim na realizacji podstawowych założeń rządu i odpieraniu ataków opozycji. W przypadku mocnych koalicji czy też zdecydowanej większości parlamentarnej danej partii nierzadko występuje zjawisko nieliczenia się $\mathrm{z}$ wyborcami w kwestii realizacji deklarowanych wartości w programach wyborczych - wówczas często tworzenie prawa ma charakter partykularny. Grupa parlamentarna tworząca koalicję czy większość parlamentarną jest prawodawcą według swojego uznania.

W aksjologii każdego państwa istnieje ideologia oficjalna, dominująca (moralność pozytywna) - czy to świecka, czy religijna - która przejawia się w politycznym obrazie władzy, a która poprzez prawo (świeckie lub religijne) jest w stanie względnie wymusić posłuszeństwo swoich obywateli (formalnie prawo operuje najskuteczniejszą sankcją wobec adresatów norm). Dopiero po niej statuują się te wartości systemów normatywnych, które niejako zostały "dopuszczone" do rozwoju w świadomości społecznej przez prawodawcę. Poza tym rekonstrukcja wartości z systemu prawnego jest swoistą deklaracją prawodawcy, pewnym założeniem aksjologicznym, które czasem nie musi mieć wiele wspólnego z rzeczywistym obrazem w stosowaniu prawa, bo np. Konstytucja z 1952 r. zawierała dużo „ładnych” przepisów

Por. W. Lang, Prawo i moralność, Warszawa 1989, s. 43-47.

Por. L. Leszczyński, Aksjologia, polityka i technika legislacyjna [w:] tenże, Podejmowanie decyzji prawnych. Tworzenie i stosowanie prawa, WSZiA, Zamość 2003, s. 16. Na marginesie rozważań mogę podać przykład ruchu społecznego „Solidarność” w Polsce oraz pluralizm światopoglądowy, jaki nastał w Polsce po 1989 r., kiedy to w księgarniach zaczęły ukazywać się tłumaczenia książek o różnych światopoglądach religijno-filozoficznych, które wcześniej były niedostępne. 
prawnych, z których nic jednak nie wynikało dla praktyki prawniczej (nie licząc ówczesnej władzy, oczywiście).

Należy również pamiętać, że czym innym jest demokratyczny wybór przedstawicieli narodu (posłów i senatorów do parlamentu), a czym innym późniejsza sprawowana przez nich władza, zwłaszcza w ramach samodzielnego rządzenia (w przypadku posiadania zdecydowanej większości w parlamencie lub w koalicji - co wiąże się „naginaniem” się do koalicjanta za cenę wspólnego przetrwania). Ta kadencyjna władza wcale nie musi być demokratyczna, bo poza programem politycznym (partyjnym, który wcale nie musi odzwierciedlać racji, lub też potrzeb społecznych), nie zawsze dającym się zrealizować (obietnice wyborcze), zainteresowana jest z reguły „przetrwaniem" do końca kadencji - z powodów materialnych, politycznych lub innych. Jeśli do tego dodamy również obsadzenie przez taki parlament (uzupełnienie $\mathrm{w}$ ramach rotacji lub kadencyjnych zmian) ludźmi o tym samym światopoglądzie politycznym (czy aksjologii) ważnych stanowisk w państwie, takich jak np. marszałek sejmu, senatu, sędziowie TK, SN, członkowie KRRiT, NIK czy nawet KRS, innych konstytucyjnych ciał czy niektórych ministerstw - rządzenie państwem do końca kadencji jest względnie niezagrożone ${ }^{4}$.

Innymi słowy, demokratyczny wybór posłów i senatorów (przedstawicieli narodu) nie implikuje demokratycznego sprawowania rządów, a jedynie legitymizuje wybór władzy ustawodawczej, wykonawczej, a pośrednio (w przypadku rotacji stanowisk niektórych instytucji) i sądowniczej, która swoją działalnością orzeczniczą może „utrwalać” określony system wartości (np. aktualnego prawodawcy).

\section{Racjonalność stanowienia prawa - konflikt normatywny czy aksjologiczny?}

Model tworzenia prawa zakłada milczącą racjonalność prawotwórczą parlamentu, który politycznie przedstawia sobą mniejsze lub większe koalicje lub przewodnictwo jednej opcji politycznej. Należy pamiętać, że przy każdym akcie kreacji prawa, odbywa się dyskusja nad jego treścią i możliwymi skutkami, a następnie głosowanie, które wyraża już tylko siłę arytmetyki oraz oczywiście układów politycznych. Jeżeli koalicja i opozycja są w opozycji merytorycznej wobec danej materii ustawodawczej, nie można mówić o tym, że przy tworzeniu prawa faktycznie do głosu dochodzi rzeczywista racjonalność, bo jest to wyłącznie założenie racjonalności większo-

Por. G. Sartori, Teoria demokratycznej dyktatury, [w:] tenże, Teoria demokracji, Warszawa 1998, s. 576 in. 
ści parlamentarnej, a nie całego parlamentu. Nawet gdyby zgodził się on co do treści i rozwiązań proceduralnych tejże, to też jest to założenie wyłącznie entymematyczne, bo adresaci norm nie reprezentują sobą monizmu aksjologicznego, którego egzemplifikacją jest właśnie rzekoma wola prawodawcy (jako woli narodu).

Owa racjonalność jest przede wszystkim założeniem modelowym i to $\mathrm{w}$ dodatku apriorycznym, bo dopiero rzeczywiste stosowanie prawa pokazuje nam obraz owej racjonalności - racjonalność ta jest domniemywana, ale nie faktyczna.

Wcześniejsze założenia L. Nowaka dotyczące doskonałego prawodawcy prawdopodobnie odpowiadały duchowi poprzedniej epoki:

1) wiedza $W_{L}$ prawodawcy L jest niesprzeczna (p1);

2) wiedza $W_{L}$ prawodawcy L jest systemem, to znaczy należą do niej jej własne konsekwencje logiczne (p2);

3) wiedza $W_{L}$ obejmuje wszystkie reguły języka, w jakim formułuje przepisy prawodawca L (p3);

4) wiedza $W_{L}$ jest najlepiej uzasadnioną wiedzą $z$ punktu widzenia aktualnego stanu nauki (p4);

5) preferencje prawodawcy L są asymetryczne, to znaczy: jeśli L przedkłada jeden stan rzeczy nad drugi, to nie przedkłada drugiego nad pierwszy (p5);

6) preferencje prawodawcy L są przechodnie, to znaczy: jeśli L przedkłada jeden stan rzeczy nad drugi, drugi nad trzeci, to L przedkłada pierwszy stan nad trzeci (p6);

7) oceny prawodawcy L wyznaczające jego preferencje są pełnym systemem słusznych moralnie ocen $(p 7)^{5}$.

Dalej L. Nowak konstatuje: „prawodawcę, który spełnia założenia p1, p2, p5 i p6, nazywam prawodawcą racjonalnym. Prawodawcę racjonalnego, który dodatkowo spełnia założenia p3, p4 i p7, nazywam prawodawcą wewnętrznie doskonałym" ${ }^{6}$. Innymi słowy - ustawodawca, który spełnia te siedem założeń, jest i racjonalny, i wewnętrznie doskonały.

Już w połowie lat 70. XX w. zwrócono uwagę na zbyt idealizujący charakter pierwszych dwóch założeń ${ }^{7}$. Zasygnalizować tylko można fakt, że jeśli ustawodawca nawet przy braku rozwoju wiedzy (danej niezmieniającej się aktualnie wiedzy czy nauk w ogóle), w tym samym składzie osobowym (w tej

Zob. L. Nowak, Interpretacja prawnicza. Studium z metodologii prawoznawstwa, Warszawa 1973, s. 53 i n.

Tamże, s. 54.

Por. W. Lang. L. Morawski, T. Gawrysiak, Interpretacja prawnicza jako szczególny rodzaj interpretacji humanistycznej, „Studia Filozoficzne” 1975, nr 12, s. 130. 
samej kadencji parlamentu) - czyli zakładając, że występuje: p1, p2 i p4 - dokonuje nowelizacji (zmiany, uzupełnienia, czy nawet derogacji przepisów prawa), to podważa tym samym własne (wymienione wcześniej) założenia (jedno lub wiele, w zależności od konkretnego przypadku). Znajduje to swoje teoretyczne uzasadnienie $w$ krajach o niedemokratycznym modelu sprawowania władzy, gdzie może do tej pory obowiązuje maksyma „sędzia jest ustami ustawy" ze wskazaniami politycznymi władzy. Poza tym trudno doszukać się logiki (racjonalności) w uchwalaniu takiego prawa, skoro o jego bycie decyduje głosowanie, więc siła liczb, a nie racjonalność. Gdyby wszelkie głosowania przebiegały jednomyślnie - i to w sposób niewymuszony partyjną dyscypliną - to na pewno uchwalonemu w ten sposób prawu przysługiwałaby większa „moc” zgodności, ale jeszcze nie racjonalności; dopiero „życie” takiego prawa byłoby swoistym testem racjonalności.

Nie wdając się w tego typu dyskusje odnośnie wymienionych założeń, już prima facie można wskazać na dość arbitralny charakter założenia 7. Poza tym trudno byłoby wykazać racjonalność związaną z etycznym wymiarem prawa, jak np. w przypadku aborcji czy eutanazji. Wydaje się, że we współczesnych demokracjach pluralizm wartości wymusił odejście od tak rozumianej woli ustawodawcy, co najbardziej widoczne jest w krajach common law.

Po roku 1989 już jawnie zaczęto formułować oceny dotyczące racjonalnego prawodawcy i tak Z. Ziembiński skonstatował, że:

W przypadku „prawodawcy” ma się do czynienia z sytuacją szczególnie skomplikowaną. Z jednej strony [spotykamy się] z fikcją metodologiczną, przyjmowaną przez dogmatykę, iż prawodawca jest określoną jedną osobą ustanawiającą normy prawne, przy czym osobą poniekąd nieśmiertelną, gdyż w przypadku ciągłości systemu prawnego obowiązuje nadal to, co ustanowiono przed laty „z woli prawodawcy”. Z drugiej strony przyjmuje się założenia idealizacyjne, mniej lub bardziej niezgodne z rzeczywistością [...] iż działania owego „prawodawcy" są działaniami racjonalnymi na gruncie przypisywanej mu wiedzy i ocen ${ }^{8}$.

Zmienny kadencyjnie i aksjologicznie (politycznie) ustawodawca tworzy właśnie takie prawo, które rozwój gospodarczy czy techniczny, a także krzyżujące się interesy określonych grup (lobbing, np. zbrojeniowy, farma-

Z. Ziembiński, Założenie racjonalnego prawodawcy, [w:] tenże, Wstęp do aksjologii dla prawników, Warszawa 1990, s. 163. 
ceutyczny, tytoniowy, ekologiczny, hazardowy czy pracodawców itp.) oraz upływ czasu w jakimś stopniu jakby dewaluują. Stąd dość często następują nowelizacje, tj. poprawianie i uzupełnianie prawa, albo uchylenie jego obowiązywania - pod konkretnych nadawców postulatów, uwikłanych jeszcze w kampanie wyborcze decydentów tworzących prawodawcę (za niektórymi politykami stoją koncerny czy korporacje; tak naprawdę nie chodzi im wcale o dobro społeczne, tylko o dobro określonych ludzi - to wszystko wpływa na system prawny, a także na późniejsze stosowanie prawa) ${ }^{9}$.

Jeżeli ustawa była uchwalona kilka lat temu oraz sam prawodawca uległ zmianie, to co możemy powiedzieć o tzw. woli ustawodawcy i celu, dla jakiego zostało uchwalone określone prawo? Można by zapytać, o jaką wolę rzeczywiście chodzi: przeszłą, teraźniejszą czy przyszłą, bo np. zaraz zmieni się skład osobowy parlamentu. Poszukiwanie owej woli utrudniają też zmiany gospodarcze, społeczne, aksjologiczne i oczywiście te polityczne, w tym i zmiany na arenie międzynarodowej (zobowiązania międzynarodowe w ramach umów czy przystąpienia do różnych układów). Wraz z samą zmianą prawodawcy (partii A, B, C i D, koalicji D i F, C i G itd.) ustawy raczej zmianom nie podlegają (nie licząc poprawek czy nowelizacji). Nie trzeba nikogo przekonywać, że za tzw. wolą ustawodawcy i zmienną co do treści stoi określona aksjologia partyjna - jako wizja przyszłości - lub określony kompromis legislacyjno-polityczny w przypadku koalicji. Nadaje to prawu przymiot „techniki społecznej” o różnym stopniu programowania i sterowania społecznego za pomocą aparatu władzy, co wcale nie musi oznaczać zmian na lepsze w rządzeniu państwem, jeśli nie ma konsensusu aksjologicznego w kluczowych sprawach polityki społecznej państwa, która dotyczy ważkich praw wolności samodecydowania (np. aborcja, eutanazja itp. $)^{10}$.

Wola ustawodawcy, wyrażona głównie jako normy prawa materialnego, będąca wynikiem aktualnej i niesprzecznej wiedzy, reguluje dany typ stosunków prawnych na „sposób A1”, kolejny prawodawca poprawia poprzednika i wprowadza „sposób A2", a następny deroguje tę ustawową materię normującą dany aspekt życia. Co wówczas możemy powiedzieć o woli ustawodawcy?

Por. np. R. Dworkin, Kim są twórcy ustawy, [w:] tenże, Imperium prawa, Warszawa 2006, s. 322 i n., oraz np. S. Waltoś, Korektury procedury prawnej po noweli z 10 stycznia 2003 r., [w:] Zagubiona szybkość procesu karnego. Światto w tunelu, red. S. Waltoś, J. Czapska, Kraków 2007, s. 38 i n. Por. np. L. Morawski, Prawo jako technika społeczna, [w:] tenże, Główne problemy wspótczesnej filozofii prawa. Prawo w toku przemian, Warszawa 2003, s. 82-91; H. Rot, Wartości demokratyczne i racjonalistyczne stadium ustanawiania aktów prawotwórczych, [w:] tenże, Demokratyczne państwo prawne (aksjologia, struktura, funkcje). Studia i szkice, Wrocław 1994, s. 123; A. Kozak, Wola prawodawcy przeciw samowoli prawnika, [w:] tenże, Granice prawniczej władzy dyskrecjonalnej, Wrocław, 2002, s. 112 i n. 
Takie zmiany tylko rozmywają określony cel regulacji i jej wartość społeczno-prawną, utrudniając tym samym stosowanie prawa przez sądy, kiedy to decydent powinien (musi) odczytać ową wolę ${ }^{11}$.

Postępowanie „zmusza” interpretatora przepisów prawnych [...] do ujmowania wiedzy prawodawcy jako wiedzy wewnętrznie niesprzecznej i konsekwentnej dedukcyjnie, a przy tym do jej historycznego ujmowania, tzn. do ujmowania jej w kategoriach właściwych optymalnemu stanowi wiedzy naukowej danej epoki (skądinąd interpretator nasz pozostaje bezradny, gdy chodzi o epokę, w której wiedza naukowa jeszcze nie wchodziła w rachubę.

Trzeba też pamiętać o tym, że nie tylko nauka wyjaśnia sporne fakty, bo dość często zmuszeni jesteśmy dokonywać ewaluacji podmiotowoprzedmiotowych, które implikują określone konsekwencje prawne i społeczne.

Przymuszony jest on tedy [interpretator] do respektowania takich poglądów, których z reguły nie akceptuje, do respektowania „logiki” niesprzeczności i konsekwencji, której sam ewentualnie nie akceptuje, a co więcej, „przymusza” analogicznie swych współczesnych sobie adresatów do akceptowania tego rodzaju przesłanek interpretacji oraz odpowiednich jej wyników, do respektowania stosownych poglądów i „logiki",

Co ma zrobić decydent prawny, kiedy czuje, że podjęta przez niego decyzja prawna może być w opozycji do jego przekonania sędziowskiego czy prokuratorskiego (tj. do moralności czy sumienia), czy nawet do doświadczenia życiowego, z którego wysnuwa on swoją mądrość? Czy ma iść za statystyką, za legalizmem prawnym decyzji, za tą hipotetyczną wolą ustawodawcy - czy za głosem „sumienia”, skoro prawo daje mu taką możliwość już w rocie sędziowskiej? Jeśli pójdzie za głosem sumienia, a w II instancji wyrok zostanie uchylony i konieczne będzie ponowne rozpatrzenie sprawy - czy dalej ma trwać w tej patowej sytuacji, czy w końcu ma się „poddać” na rzecz

${ }^{11}$ Na temat demokracji zob. szerzej T. Sasińska-Klas, Modele demokracji. Klasyczne założenia i ich wspótczesne odmiany, [w:] Prawo w zmieniającym się spoleczeństwie, red. G. Skąpska, Kraków 1992, s. 349-365.

12 J. Kmita, Etyczny aspekt koncepcji racjonalnego prawodawcy, [w:] Szkice z teorii prawa i szczegótowych nauk prawnych, red. S. Wronkowska, M. Zieliński, Poznań 1990, s. 423; zob. także: S. Wronkowska, Prawodawca racjonalny jako wzór dla prawodawcy faktycznego, [w:] Szkice z teorii prawa i szczególowych nauk prawnych, s. 128 i n. 
„wskazań” II instancji i podjąć konfliktową i moralnie niewłaściwą decyzję? Czy może ma się wyłączyć ze sprawy, bo nie chce być w takiej konformistycznej sytuacji, która tak naprawdę dotyczyć będzie i jego, i podsądnego, który jakby podwójnie jest skazany (przez system prawny i przez aksjologię decydenta prawnego)? A przecież wiemy, jak dużo zależy od aksjologii podmiotu stosującego prawo.

Decydent prawny, zwłaszcza sędzia, nie musi „czuć” w zgodzie z tą nieokreśloną, zmieniającą się politycznie i aksjologicznie (także i doktrynalnie) wolą ustawodawcy, a czasem i niedookreślonym interpretacyjnie znaczeniem tekstu prawnego (normy prawnej). Do tego dochodzi jeszcze wykładnia, która nie daje gwarancji poprawności merytorycznej, bo przecież sąd II instancji czy kasacyjny wytyka „błędy", które w ocenie pierwszego sądu nie są (nie były) błędami, nie daje też zgodności etycznej decyzji prawnej na liniach ustawodawca-decydent prawny i decydent prawny-strona procesowa, bo o tej chyba ustawodawca zapomniał lub świadomie nie wziął jej po uwagę.

„Sąd ma postępować racjonalnie nie tylko sporządzając uzasadnienie, ale także ma racjonalnie postąpić w zakresie wykładni prawa, czyli dokonać racjonalnej wykładni (racjonalność rozumowania). Analizując postępowanie adresatów, musi im z kolei postawić warunki racjonalności. Racjonalność wykładni ma ściśle związek z racjonalnością prawodawcy. Sąd powinien uwzględniać racjonalne skutki regulacji prawnych i nie zapominać o zdrowym rozsądku, który zresztą w znacznej części orzeczeń występuje pod nazwą «racjonalność»"

Gdybyśmy rzeczywiście mieli dać prymat hipotetycznie racjonalnemu prawu, ustanowionemu przez ustawodawcę, to każde - nawet niemoralne i błędne - prawo musiałoby być stosowane przez decydentów prawnych racjonalność byłaby „poszukiwana” na siłę. Gdyby założyć nieomylność ustawodawcy, prawo byłoby raczej doskonałe i nie podlegające poprawie $\mathrm{w}$ danej materii, a jedynie uzupełniane o nową. Czym byłoby orzecznictwo SN, TK lub trybunałów europejskich, które mogłyby wytykać błędy w tworzeniu prawa (np. niekonstytucyjność)? Gdzie wówczas byłaby swobodna ocena dowodów decydentów prawnych oraz ich autonomia ewaluacyjna wobec trudnych przypadków lub nienormowanych w prawie spraw? Czy byłaby ona już dokonana przez prawodawcę?

Prawodawca tworzy normy abstrakcyjne, które przybierają postać norm konkretnych w stosowaniu prawa wobec określonego człowieka, a sę-

13 R. Piszko, Racjonalność w orzecznictwie sądów, [w:] tenże, Wyznaczniki treści i obowiązywania dyrektyw wykładni prawa w prawoznawstwie i w praktyce prawniczej, Szczecin 2007, s. 137. 
dzia czy prokurator mają bezpośrednią możliwość poznania sprawy, stron procesu, ich wniosków czy wyjaśnień, które mogą zmienić kierunek postępowania sądowego. W tym bezpośrednim kontakcie decydentów prawnych ze stanem faktycznym dochodzi do rzeczywistego wartościowania realnych i konkretnych faktów, a nie tylko hipotetycznych, które miały miejsce w przypadku tworzenia prawa przez ustawodawcę. Nie można mówić o racjonalności apriorycznej prawodawcy, bo i tak stosowanie prawa nabiera realnych kształtów dopiero w momencie poznawania stron procesowych czy odtwarzania zdarzeń. Ustawodawca niejako przekazuje swoją wolę sądownictwu (trybunałom) i w tym zaznacza się rzeczywista separacja od władzy ustawodawczej. Jeśli mamy mówić o stosowaniu prawa w sposób pozbawiony „sugestii" ustawodawcy, to sędziwie i prokuratorzy muszą podlegać ustawom, a nie woli prawodawcy, którą każdy może odczytać inaczej (cel ustawy, intencje zmiennego prawodawcy).

Prawodawca w Konstytucji określa w sposób dość abstrakcyjny główne zasady funkcjonowania władzy państwowej, prawa i praw obywatelskich na straży których ma stać dodatkowy organ zwany Trybunałem Konstytucyjnym. W jego gestii też leży ingerencja $\mathrm{w}$ niewłaściwie pojmowaną wolę czy intencję ustawodawcy przy stosowaniu prawa przez sądy powszechne czego dowodem są wyroki TK o niezgodności z abstrakcyjnie pojmowanymi wartościami danych norm, wyrażonymi klauzulowo w konkretnej sprawie.

Analiza wyroków TK pokazuje, że mamy ich aż 7 rodzajów. Za podstawowe uważam dwa wyroki: o zgodności z konstytucją i o niezgodności z konstytucją odpowiedniego przepisu lub całego aktu prawnego, np. ustawy. Pomiędzy tymi orzeczeniami znajdują się orzeczenia, które: 1) uznają przepis za zgodny pod warunkiem odpowiedniego rozumienia, 2) uznają przepis za zgodny w odpowiednim zakresie jego stosowania (podmiotowym, przedmiotowym, czasowym), 3) uznają przepis za niezgodny pod warunkiem rozumienia go w określony sposób, 4) uznają przepis za niezgodny w odpowiednim zakresie jego stosowania [...] Orzeczenia stwierdzające zgodność lub niezgodność ustawy z konstytucją, używające formuły „art. X rozumiany jako” lub „art. X rozumiany w sposób" jest zgodny lub niezgodny z konstytucją - wydawane są w zasadzie w sytuacji, gdy przepis ustawy nie jest jasno sformułowany i przez to jest od po- 
czątku wieloznaczny lub nadawany jest mu w praktyce sens różny, co także wskazuje na jego wieloznaczność ${ }^{14}$.

Teraz można by zapytać, czy chodzi o wolę ustawodawcy takiego a nie innego rozumienia przepisów prawnych, czy o ich rozumienie przez TK lub SN, które mocą urzędu zawsze są bliższe „prawdy” niż ustawodawca lub sądy powszechne.

Poza tym to nie ustawodawca, który ceduje swoją wolę na decydentów prawnych, ponosi odpowiedzialność (prawną czy dyscyplinarną) za niewłaściwe rozumienie i stosowanie prawa (narzucone kontekstowo czy intencjonalnie określone rozumienie danych przepisów prawnych), tylko konkretny sędzia czy prokurator. Koszty takich ,pomyłek” czy błędów ponosimy z kolei my wszyscy, a nie hipotetyczny prawodawca, który co najwyżej za jakiś czas może ulec mniejszej lub większej pod względem personalnym zmianie. Żaden sędzia czy prokurator nie wystąpi wówczas do prawodawcy o poniesienie konsekwencji materialnych czy prawnych wobec narzucenia mu takiego a nie innego rozumienia prawa. A odpowiedzialność polityczna nie zaspokoi społecznego poczucia sprawiedliwości, a tym bardziej nie naprawi błędów, które mogły zaistnieć w stosowaniu prawa pod dyktando woli prawodawcy. Dlatego trzeba $\mathrm{z}$ dużą ostrożnością podchodzić do oryginalnego znaczenia norm, intencji czy woli prawodawcy, i jeśli naprawdę chcemy nie rozmywać odpowiedzialności prawnej, moralnej i społecznej (także i ekonomicznej w przypadku wypłaty odszkodowania za błędy w stosowaniu prawa) - to musimy mieć tego normatywną i moralną świadomość, zastanowić się, co możemy zrobić, aby takie konflikty maksymalnie zniwelować, by za stosowanie prawa byli odpowiedzialni jego twórcy i decydenci prawni, by można było też określić optymalne stosowanie prawa bez tego uwikłania się strukturalnego i aksjologicznego prawodawcy, które przeczy zasadom i niezawisłości, i bezstronności.

Sędziowie wymierzają sprawiedliwość na podstawie prawa (sprawiedliwość proceduralna) i własnego sumienia (konkretne rozstrzygnięcia prawne na podstawie ewaluacji etyczno-psychologicznej w granicach prawa), prokuratorzy również - więc jeśli mają pracować na własny rachunek, a nie kryć się za różną aksjologicznie i zmieniającą się wolą prawodawcy czy ucieczką w legalizm, powinni być niezależni, ale też i odpowiednio wrażliwi społecznie i zdystansowani aksjologicznie w kwestii wpływu prywatnych preferencji na ocenę prawną (możliwość zachowania neutralności czy obiek-

${ }^{14}$ J. Trzciński, Trybunal Konstytucyjny - regulacja konstytucyjna i praktyka, [w:] Sądy i trybunaty w konstytucji i praktyce, red. W. Skrzydło, Warszawa 2005, s. 93. 
tywizmu - co nie znaczy, że w takim przypadku w ogóle nie można dokonać ewaluacji) ${ }^{15}$.

Decydent prawny jest podmiotem prawa i podmiotem ludzkim, który poprzez własne rozumienie tekstu prawnego, poprzez osobiste postrzeganie podsądnego, jego sytuacji życiowej, jego aksjologii, jego motywacji, zachowań i celów dokonuje ewaluacji tych ustawowo zapisanych determinantów decyzji prawnej (zwłaszcza w postępowaniu karnym) oraz nieustawowo zapisanych w jego osobowości, psychice, moralności, o których zaczyna się coraz głośniej mówić, a czego egzemplifikacją są zdania odrębne, zasada głosowania nad orzeczeniem i jego głównymi postanowieniami, różne wysokości konsekwencji prawnych i w końcu - niejednolitość stosowania prawa i orzecznictwa.

Jeżeli już w samej rocie ślubowania sędziowskiego decydent prawny przysięga jako sędzia sądu powszechnego służyć wiernie Rzeczypospolitej Polskiej, stać na straży prawa, obowiązki sędziego wypełniać sumiennie oraz sprawiedliwość wymierzać zgodnie z przepisami prawa, bezstronnie według swojego sumienia, a w postępowaniu kierować się zasadami godności i uczciwości, to wynika $\mathrm{z}$ tego, że omnipotencja jedynej wykładni zgodnej z wolą ustawodawcy jest małą fikcją, a rozbieżność orzecznictwa i niejednolitość w stosowaniu prawa są tego dowodem, choć w języku prawnym nazywać się będą „obrazą" prawa lub „naruszeniem” reguł prawnych (pomijam oczywiście ewidentne błędy w procedurze, które na szczęście są dostrzegane w czasie kontroli).

Jednak mimo takich zapisów roty w przeszłości bardzo często dochodziło do kierowania się oficjalną, legalną czy formalną wykładnią dokonywaną przez najwyższe organy państwowe (np. Radę Państwa, która miała uprawnienia powoływania sędziów SN i prokuratora generalnego), a sędzia czy prokurator był jedynie „przedłużeniem” sprawiedliwości oficjalnej (co nie znaczy, że był „ubezwłasnowolniony” decyzyjnie) ${ }^{16}$.

15 Każdy z nas może dokonać oceny osoby, czynów przez pryzmat silnego zaangażowania we własną aksjologię oraz oceny bez takiego zaangażowania, a która np. bardziej opierałaby się na możliwym dystansie czy na współzaistnieniu wielu ocennych kontekstów w ewaluacji.

16 Rada Państwa była kolegialną głową państwa, i to w oparciu o jej preferencje powoływano prokuratora generalnego, Sąd Najwyższy czy NIK. Miała też uprawnienia dokonywania powszechnie obowiązującej wykładni ustaw i dekretów z mocą ustawy, a także ustalała zasady stosowania tych przepisów. Ustawa z 20 lipca 1950 r. zwiększyła zakres ustalania powszechnie obowiązującej wykładni o ogólne przepisy prawne. Rada korzystała z tego uprawnienia rzadko, bo zdawano sobie sprawę z tego, że taka działalność mogłaby sugerować sądom i administracji własne rozumienie i pojmowanie woli sejmu danej materii prawnej, ograniczając tym samym autonomiczność III władzy. Natomiast owe „sugestie” interpretacyjne $\mathrm{w}$ doniosłych dla funkcjonowania państwa sprawach (a nawet i w przypadku określonych osób) podawane były drogą nieoficjalną, by nie powiedzieć - partyjną, por. A. Burda, Polskie prawo państwowe, Warszawa 1976, s. 282 i n. 
Czasem z analizy tekstu prawnego może wynikać wiele możliwości interpretacyjnych, mniej lub bardziej zgodnych z wolą ustawodawcy w chwili uchwalenia danego prawa czy już w chwili wpływu orzecznictwa SN lub TK (tj. możliwe rozumienia danych przepisów czy też wiele konsekwencji prawnych, które zostały zaaplikowane przez sądy powszechne). Wówczas decydent prawny jest jakby nieformalnie „ukierunkowywany" na rozumienie danego przepisu prawnego właśnie w takim a nie innym kontekście, bo zdaje sobie sprawę $\mathrm{z}$ tego, że $\mathrm{w}$ toku postępowania odwoławczego jego rozumienie może zostać podważone. Przecież w stosowaniu prawa z ewaluacji i rozumienia faktów, zdarzeń, osób - innymi słowy: dowodów - wynikają incydentalne postanowienia i finalne orzeczenie.

W opozycji do poszukiwania intencji czy woli prawodawcy stoi inkoherencja w rozumieniu, a później i aplikacji prawa, której należy szukać w następujących czynnikach związanych z podmiotem stosującym prawo:

1) nieostrość i wieloznaczność języka prawnego, tj. w niedookreślenie zwrotów i wyrażeń (otwarte pole semantyczne) ${ }^{17}$;

2) kontekstowość użycia wymieionych terminów z obszaru języka potocznego i prawnego;

3) poszukiwanie takiej wykładni prawa, która byłaby zgodna z wolą prawodawcy, zgodna z linią orzecznictwa i jeszcze z przekonaniem wewnętrznym decydenta (jego sumieniem), co dla decydenta byłoby optymalnym rozwiązaniem;

4) subiektywne współodczuwanie danej sprawy, przetwarzanie informacji czy rozumienie i w końcu nadawanie takich znaczeń, które wyznaczane są przez osobowość psychiczną, etyczną, społeczną czy normatywną, a znajdują swoją egzemplifikację $\mathrm{w}$ ocenach, tezach i uzasadnieniach poszczególnych etapów stosowania prawa;

5) zgodność aksjologiczna lub jej brak między ustawodawcą, decydentem prawnym i adresatami norm, gdy już adresat stanie się stroną postępowania; do tej pory była to najbardziej pomijana kwestia, jednak zaczyna się dostrzegać potrzebę realizacji tego postulatu jako alternatywnej formy rozwiązywania konfliktów („sądy uczniowskie” w Bawarii) ${ }^{18}$.

Obecnie sposób charakteryzowania prawodawcy jako autora tekstu normatywnego (a więc podmiotu, którego wola może ograniczać swobodę interpretacyjną prawnika) znacznie się zmienił. Wskazuje się tu tzw. prawodaw-

Por. M. Zirk-Sadowski, Prawo a uczestniczenie w kulturze, Łódź 1998, s. 78 i n.

A. Chomiuk-Żywalewska, Instytucja „sąów uczniowskich" w Niemczech jako alternatywne rozwiązanie przeciwdziałania przestępczości nieletnich, „Prokuratura i Prawo” 2008, nr 3, s. 139145. 
cę racjonalnego, który w żadnym wypadku nie może być utożsamiany z prawodawcą realnym. Jego racjonalność jest pojmowana przede wszystkim jako formalny związek między celem, wiedzą i środkami podejmowanymi do osiągnięcia celu przez aktora. Z punktu wiedzenia teorii interpretacyjnej należy jednak uznać, że racjonalność musi być pojęciem charakteryzującym nie tylko autora, ale i interpretatora (aby się porozumieć, obaj muszą być racjonalni, a ściślej racjonalni w ten sam sposób) ${ }^{19}$

- co przecież może wykluczać autonomiczność bądź niezawisłość, skoro prawodawca racjonalny jest władzą ustawodawczą, a sądownictwo, czy mówiąc szerzej: „wymiar sprawiedliwości” - trzecią władzą, która jest (powinna być) odporna na „naciski” pierwszej ${ }^{20}$.

Minimalizacji rozbieżności orzeczniczej i stosowaniu prawa bez istotnych dyferencjacji w wykładni dla tej samej kategorii spraw (o czym była już mowa; pomijam oczywiście ewaluację w sprawach karnych i w sprawach, w których dochodzi do oszacowania wysokości odszkodowania) mają służyć nie tylko uchwały, ale też i same orzeczenia SN czy TK (które mają charakter prejudykatów) oraz różne instytucje prawne mogące być użyte przed wydaniem finalnej decyzji (pytania prawne czy zagadnienia prawne kierowane do SN i TK), bo nie tylko SN chce utrzymania jednolitości orzecznictwa, ale też i sądy niższej instancji, które rzadko kiedy idą „pod prąd” w stosunku do orzecznictwa SN czy TK ${ }^{21}$.

19 Tak A. Kozak, Wola prawodawcy jako czynnik determinujący wykładnię, [w:] tenże, Pojmowanie prawa w teorii wykładni, Wrocław 1997, s. 74.

20 Por. także K. Daniel, Normatywny $i$ spoleczny obraz sędziego, [w:] Sądy w opinii spoleczeństwa polskiego, red. M. Borucka-Arctowa, K. Pałecki, Kraków 2003, s. 99.

${ }_{21}$ Por. np. J. Mikołajewicz, Zasady orzecznicze Trybunału Konstytucyjnego. Próba wyodrębnienia, [w:] Prawoznawstwo a praktyka stosowania prawa, red. Z. Tobor, Katowice 2002, s. 105-117, zob. także: W. Gromski, Wykładnia ustaw ustalana przez TK a model sądowego stosowania prawa, [w:] Z zagadnień wykładni prawa, red. S. Kaźmierczyk, Wrocław 1997, s. 41-49; A. Kozak, Rodzaje wykładni prawa w uchwałach Trybunału Konstytucyjnego, [w:] Z zagadnień wykładni prawa, s. 51-68. „Trybunał posługuje się w wykładni kategorią «racjonalny prawodawca» w sposób uzasadniający traktowanie tej kategorii przez część literatury prawniczej jako związanej z dynamiczną ideologią wykładni; w praktyce interpretacyjnej TK nie widać jednak niebezpieczeństw, przed którymi wspomniana literatura przestrzega; kategoria «racjonalny prawodawca» wymusza posługiwanie się rozmaitymi utrwalonymi w kulturze prawnej regułami, uniemożliwiającymi arbitralne i nieprzewidywalne rozstrzygnięcia, dlatego praktyka interpretacyjna podmiotu posługującego się tą kategorią pozostaje kontrolowana. Dla bezpieczeństwa obrotu prawnego o wiele bardziej niebezpieczne jest np. stanowisko Sądu Najwyższego w kwestii nie dających się usunąć niejasności w tekście normatywnym". Tamże, s. 67. 
Regularnie SN odwołuje się także do pozajęzykowych reguł wykładni, nawet jeśli nadal wiąże je z ideałem racjonalnego prawodawcy. Jak wskazałem, na podstawie wykładni funkcjonalnej SN może dochodzić nie tyle do ograniczenia, co do ustalenia nowego zakresu fundamentalnych zasad systemu prawa i kultury prawnej (a przy tym i Konstytucji RP), jak nullum crimen sine lege. W takich przypadkach SN wykazuje przy tym coraz więcej swobody, coraz mniej czując się związanym "literą prawa” (verba iuris). Coraz wyraźniejsza jest więc niewiara SN w obiektywny sens ustaw, coraz silniej interpretacja zakorzeniona jest w kontekście historycznym, ekonomicznym, społecznym itp ${ }^{22}$.

W takim układzie wola ustawodawcy, odczytana przez największe autorytety sędziowskie (SN czy TK) w sprawach, w których już obie instytucje zabierały głos i stworzyły tym samym normatywne quasi-podstawy przyszłych orzeczeń - ulega swoistej tranzycji aksjologicznej, i albo było to po „myśli” ustawodawcy, albo było w opozycji do niej. Stanowić to może swoiste „sprzężenie zwrotne” jako postulat zmiany prawa w określonym kierunku zasugerowanym przez przedstawicieli III władzy w kontekście postulatów woli prawodawcy. Płaszczyzną porozumienia są tu wyłącznie wartości, które nabierają konkretnego kształtu w decyzjach prawnych.

Bez większego ryzyka można powiedzieć, że kiedy wchodzi nowe prawo, sądy powszechne, a w jakimś stopniu i prokuratura, poprzez aplikacje nowej materii prawnej wytyczają nową drogę w stosowaniu prawa, która zawsze może ulec zmianie lub swoistemu przewartościowaniu właśnie przez SN czy TK (a teraz jeszcze ETS i ETPC).

Podstawowi decydenci (sądy powszechne i prokuratura) też w jakimś stopniu kierują się wolą ustawodawcy oraz, niestety, legalizmem, który jest prymarny w stosunku do nowej materii ustawowej, która dopiero zaczyna obowiązywać (tworzyć stosunki prawne). A legalizm ma przecież związek z zasadą państwa prawnego, która to wyznacza formalny kierunek każdego postępowania sądowego czy prokuratorskiego ${ }^{23}$.

22 T. Stawecki, Interpretacje prawa w orzecznictwie Sądu Najwyższego, [w:] Filozofia prawa wobec globalizmu, red. J. Stelmach, Kraków 2003, s. 103.

Postanowienie SN z dnia 29 stycznia 2009 r.: dopuszczalne, a niekiedy nawet konieczne jest doprecyzowanie znamion ustawowych niektórych czynów zabronionych w aktach rangi podustawowej, to jest $w$ rozporządzeniach. Takie działanie ustawodawcy nie narusza zasady nullum crimen sine lege, zawartej w art. 1 \$ k.k. (I KZP 29/08). 
Przystąpienie Polski do UE poszerzyło margines aksjologiczny w stosowaniu prawa przez polskie sądy o prawo międzynarodowe, bo zgodnie $\mathrm{z}$ art. 9 Konstytucji Polska przestrzega wiążącego ją prawa międzynarodowego, a:

prawną konsekwencją art. 9 Konstytucji jest konstytucyjne założenie, iż na terytorium Rzeczypospolitej Polskiej, obok norm (przepisów) stanowionych przez krajowego legislatora, obowiązują uregulowania (przepisy) kreowane poza systemem krajowych (polskich) organów prawodawczych. Ustrojodawca konstytucyjny świadomie więc przyjął, że system prawa obowiązujący na terytorium Rzeczypospolitej mieć będzie charakter wieloskładnikowy. Obok aktów prawnych, stanowionych przez krajowe (polskie) organy prawodawcze, w Polsce obowiązują i są stosowane także akty prawa międzynarodowego. Założenie wieloskładnikowej struktury systemu prawa obowiązującego w Polsce ma charakter generalny. Zostało ono przyjęte w okresie wyprzedzającym o kilka lat akcesję do Wspólnot i Unii Europejskiej. Nie można więc twierdzić, iż jest to uregulowanie epizodyczne, ukształtowane tylko w związku i na użytek przystąpienia Rzeczypospolitej Polskiej do Wspólnot i Unii Europejskiej $^{24}$.

Zrodziło to wiele wątpliwości w wielu państwach i gdyby skład osobowy trybunałów konstytucyjnych był antyeuropejski, mielibyśmy bardzo spolaryzowane argumenty i byłby one ostateczne. W Polsce na fakt przystąpienia do UE zareagowali parlamentarzyści zwłaszcza prawicowych partii, składając do TK odpowiednie wnioski o niekonstytucyjności niektórych przepisów z powodu wejścia Polski do UE.

Inicjatorzy postępowania przed Trybunałem Konstytucyjnym w niniejszej sprawie - trzy grupy posłów na Sejm RP przeciwnych członkostwu Polski w UE na warunkach wynikających z Traktatu akcesyjnego - zarzucili niezgodność akcesji w tym kształcie z Konstytucją RP, między innymi z konstytucyjnymi zasadami suwerenności Narodu i nadrzędności Konstytucji w porządku prawnym

${ }^{24}$ Wyciąg z wyroku pełnego składu TK z dnia 11 maja 2005 r., K 18/04. 
Rzeczypospolitej. Zakwestionowali w całości owe warunki akcesji, stanowiące nierozerwalną całość ${ }^{25}$.

Trybunał jakby rozwiał te wątpliwości i skonstatował, że:

Ani art. 90 ust. 1, ani też art. 91 ust. 3 Konstytucji nie upoważniają do przekazania organizacji międzynarodowej kompetencji do stanowienia aktów prawnych lub podejmowania decyzji, które byłyby sprzeczne z Konstytucją, będącą „najwyższym prawem Rzeczypospolitej Polskiej" (art. 8 ust. 1). Nie upoważniają one także do przekazania kompetencji w zakresie, który oznaczałby, iż Rzeczpospolita Polska nie może funkcjonować jako państwo suwerenne i demokratyczne. Ocena konstytucyjności przekazania niektórych kompetencji z punktu widzenia aksjologii Konstytucji RP powinna uwzględniać to, że $\mathrm{w}$ preambule Konstytucji, akcentując znaczenie odzyskanej przez Polskę możliwości suwerennego i demokratycznego stanowienia o swoim losie, ustrojodawca jednocześnie deklaruje potrzebę „współpracy ze wszystkimi krajami dla dobra Rodziny Ludzkiej”, przestrzegania obowiązku „solidarności z innymi” oraz uniwersalnych wartości, takich jak prawda i sprawiedliwość. Powinność ta odnosi się nie tylko do stosunków wewnętrznych, ale również zewnętrznych. Unormowaniu zawartemu w art. 8 ust. 1 Konstytucji, w myśl którego jest ona „najwyższym prawem Rzeczypospolitej Polskiej”, towarzyszy nakaz respektowania i przychylności wobec właściwie ukształtowanych wiążących Polskę unormowań prawa międzynarodowego (art. 9). Konstytucja zakłada więc, że na terytorium Rzeczypospolitej Polskiej, obok norm ustanowionych przez legislatora krajowego, obowiązują uregulowania kreowane poza systemem krajowych organów prawodawczych. Z racji swej nadrzędnej mocy prawnej (art. 8 ust. 1) Konstytucja korzysta na terytorium Rzeczypospolitej Polskiej z pierwszeństwa obowiązywania i stosowania. Zagwarantowane w art. 91 ust. 2 Konstytucji pierwszeństwo stosowania umów międzynarodowych, które zostały ratyfikowane na podstawie 
upoważnienia ustawowego lub podjętego (zgodnie $\mathrm{z}$ art. 90 ust. 3) w trybie ogólnokrajowego referendum, przed ustawami nie oznacza analogicznego pierwszeństwa tych umów przed Konstytucją ${ }^{26}$.

Na pewno wpływ europejskiej kultury prawnej ma i będzie mieć swoje pozytywne strony, jak np. uchwalenie w 2004 roku ustawy o skardze na naruszenie prawa strony do rozpoznania sprawy w postępowaniu sądowym bez uzasadnionej zwłoki $^{27}$. Mimo iż podstawa tego istniała już wiele lat $\mathrm{w}$ art. 45 Konstytucji - że każdy ma prawo do sprawiedliwego i jawnego rozpatrzenia sprawy bez nieuzasadnionej zwłoki przez właściwy, niezależny, bezstronny i niezawisły sąd - to trzeba było tak długo czekać, aby zapis stał się rzeczywistością prawną $^{28}$.

Gdyby wola ustawodawcy krajowego miała być zarazem i wolą III władzy (systemu sądownictwa i TK - co niestety często ma miejsce w systemach niedemokratycznych, choć czasem formalnie wszystko jest rozdzielne), to istniałby w rzeczywistości hegemonia tylko jednej władzy, która wybierałaby do najważniejszych urzędów (organów) odpowiednich ludzi, a sędziowie czy prokuratorzy (częściowo też pozostali prawnicy) byliby tylko swoistą częścią władzy ustawodawczej (wystąpiłaby zgodność woli, w której stosowanie prawa korespondowałoby z władzą wykonawczą, bo władza wykonawcza byłaby też tylko ramieniem władzy ustawodawczej). Legitymację na kierowanie życiem w państwie poprzez prawo miałaby tylko władza ustawodawcza, a to już explicite oznaczałoby totalitaryzm $\mathrm{w}$ różnych jego odmianach czy pierwotny pozytywizm, dla którego nie treść, ale forma prawa miała największe znaczenie.

Nie trzeba już nikogo przekonywać, że taka omnipotencja prawna (wręcz monizm aksjologiczny) ustawodawcy bez jakiejkolwiek kontroli pokazywała nieludzkie oblicze aparatu rządzenia, który musiał utrzymywać się „siłą” przy władzy, co jeszcze i dziś ma miejsce na świecie, a bezpieczeństwo prawne, pozory legalności oraz kontrola społeczna odbywająca się poprzez

\section{Tamże.}

Ustawa z dnia 17 czerwca 2004 r. wpłynęła na obowiązywanie realizacji prawa do rozsądnego terminu, który był w Polsce nagminnie nieprzestrzegany, choć wynikał już z art. 45 Konstytucji. Zasada rozsądnego terminu wprowadzona była do krajowego systemu prawnego wraz z ratyfikacją europejskiej Konwencji o Ochronie Praw Człowieka i Podstawowych Wolności (w art. 6.). 1 maja 1993 r. Polska weszła pod jurysdykcję Europejskiego Trybunału Praw Człowieka w Strasburgu, który stoi na straży przestrzegania tego aktu prawa. Podsumowanie funkcjonowania tej ustawy w latach 2005 i 2006 oraz koszty ekonomiczne przedstawiła D. Szumiało-Kulczycka, Ustawa o skardze na naruszenie prawa strony do rozpoznania sprawy w postępowaniu sądowym bez zbędnej zwloki w świetle orzecznictwa i danych empirycznych, [w:] Zagubiona szybkość procesu karnego, s. 47-57. 
prawo niejednokrotnie prowadziły po prostu do ustawowego bezprawia w imię litery prawa ${ }^{29}$.

Wola ustawodawcy może zakreślać abstrakcyjne cele regulacji prawnych czy też wykładni, których kierunkowość i racjonalność zostaną dopiero sprawdzone w procesie stosowania prawa, przy czym już wystąpienie do TK z pytaniem o konstytucyjność takich czy innych unormowań może podważyć, a nawet zanegować, racjonalność lub byt woli prawodawcy, co w istocie świadczyłoby o sprawnym i funkcjonalnym podziale i niezależności władz oraz o hipotetycznej racjonalności ustawodawcy, którego tworzą wskazane wyżej zbiorowe podmioty.

Sprawa zaczyna znacznie się komplikować, kiedy do „głosu” dochodzi konflikt woli ustawodawców krajowego i europejskiego, który przybiera postać konkretnych orzeczeń wydanych na mocy prawa krajowego czy unijnego.

Można np. mieć wątpliwości co do pełnego urzeczywistnienia zasady nadzoru judykacyjnego Sądu Najwyższego $\mathrm{w}$ razie jego związania wyrokiem wstępnym ETS. Przewartościowania wymagałaby przede wszystkim jednak niezawisłość sędziowska. Konstytucyjny standard, w myśl którego: „sędziowie w sprawowaniu swojego urzędu są niezawiśli i podlegają tylko Konstytucji oraz ustawom" (art. 178 ust. 1) jest anachroniczny m.in. na skutek przystąpienia RP do UE. Nawet jeśli dzięki wykładni systemowej uwzględniającej odesłania do art. 9, 87, 91 Konstytucji udałoby się poszerzyć wzorzec podległości o akty prawa unijnego (byłoby to jednak sprzeczne z zasadą exceptiones non sunt extendendae), to rodzi się pytanie, jak połączyć związanie sędziego ustawą z sądowym stosowaniem prawa wspólnotowego w razie konfliktu tych obu źródeł prawa. Kto miałby orzekać o niestosowaniu ustawy sprzecznej np. z rozporządzeniem UE, skoro sędzia w zgodzie z art. 178 ust. 1 jej podlega? Sprawę komplikuje mocno rozwijana w orzecznictwie ETS zasada absolutnego i bezwarunkowego pierwszeństwa prawa wspólnotowego (również wobec konstytucji państw członkowskich). Czy zatem polski sędzia, stosując prawo UE, podlegałby jedynie temu prawu i wątpliwej z punktu

Por. np. J. Stelmach, Filozoficzne aspekty dyskusji o państwie prawnym, [w:] Państwo prawa. Demokratyczne państwo prawne. Antologia, red. J. Kowalski, Warszawa 2008, s. 93. 
widzenia statusu ontycznego zasadzie supremacji nawet wtórnego prawa wspólnotowego ${ }^{30}$ ?

Skoro wiemy, że aksjologia każdego decydenta prawnego jest najważniejszą determinantą (zawiera w sobie różne obszary normatywne i ich wartości) większości decyzji prawnych (pomijam proste decyzje), to jak mogłaby przedstawiać się sprawa orzecznictwa europejskich trybunałów wobec krajowych sądów (porządków prawnych), gdyby skład orzeczniczy trybunału zdominowany był jakże różnymi wartościami religijnymi czy światopoglądowymi decydentów prawnych? Obywatelami krajów wchodzących w skład UE jest wiele nacji, grup etnicznych czy religijnych o bardzo zróżnicowanej, czasem wykluczającej się aksjologii. Gdyby właśnie taki skład miał orzekać o prawach i wolnościach np. religijnych (praktyk, ubioru czy statusu przedmałżeńskiego kobiety i innych) mniejszości religijnej w danym kraju UE (zakładam zgodność aksjologiczną składu trybunału z tą mniejszością, np. zgodność religijną) $)^{31}$, to jakie wartości prawne miałyby pierwszeństwo? Wartości zróżnicowanej, niejednorodnej europejskiej kultury prawnej, krajowej kultury prawnej danego państwa czy pozaeuropejskiej kultury prawnej, które choć niegdzie formalnie nie wskazane, to jednak znajdują się w sumieniu właśnie tychże decydentów prawnych, którzy tymczasowo zasiadają w trybunale europejskim i orzekają o uprawnieniach obcych danej kulturze krajowej, którego obywatele wnieśli skargę przez trybunał. Przecież to ludzie tworzą prawo i oni też je interpretują oraz implementują do jego wykładni własną aksjologię czy kulturę prawną, i każdy decydent prawny, stosując to samo prawo, może dojść do zupełnie odmiennych konsekwencji prawnych.

Legalizm jakiej kultury prawnej jest prymarny (supremacyjny) $\mathrm{w}$ takim konflikcie wartości różnych kultur prawnych, które wyrażają się poprzez pluralizm charakterystycznej dla danego państwa czy danego narodu aksjologii? Jak w takim układzie wygląda zasada bezstronności sędziowskiej czy neutralności etycznej, religijnej czy światopoglądowej w stosowaniu prawa przez obce sądy i trybunały? Co rzeczywiście przesądza o legitymacji takich orzeczeń? Wartość merytoryczna (prawna) sprawy, wartość narodowa (w kontekście kultury prawnej), etniczna danej grupy społecznej (której przedstawicielem może być decydent prawny) czy moc instancyjna sądu lub trybunału? Gdyby zmienić podmioty w danym składzie sądu (trybunału), to wydane orzeczenie byłoby dokładnie przeciwne niż to, które początkowo zostało „zaskarżone” przez stronę postępowania. Przykładem konfliktu warto-

${ }^{30}$ J. Galster, Z. Witkowski, Akcesja Rzeczpospolitej Polskiej do Unii Europejskiej. Konsekwencje dla sadownictwa, [w:] Sady i trybunaly w konstytucji i praktyce, s. 146.

31 Głośną sprawą był zakaz noszenia chust na głowach przez muzułmanki w szkołach publicznych we Francji i w Niemczech. 
ści prawnych z innymi wartościami, może być casus polskiego Roma na Dolnym Śląsku.

Marka K. oskarżono o to, że mając 18 lat, poślubił niemającą jeszcze 15 lat Romkę, co w zwyczajach Cyganów jest normalne (wielowiekowa tradycja). Kobieta urodziła dziecko, będąc w 15. roku życia, co oznaczało, że oskarżony obcował płciowo ze swoją małżonką (czy wówczas narzeczoną), a to było już niestety naruszeniem norm prawa polskiego, tj. art. 200 k.k., czyli: „kto obcuje płciowo z małoletnim poniżej lat 15 lub dopuszcza się wobec takiej osoby innej czynności seksualnej lub doprowadza ją do poddania się takim czynnościom albo do ich wykonania, podlega karze pozbawienia wolności od lat 2 do 12 ". Ślub odbył się w roku 2003, a sprawa sądowa w $2007^{32}$. W dodatku prawo polskie w art. 106a k.k., stanowi, że nie podlega zatarciu skazanie na karę pozbawienia wolności bez warunkowego zawieszenia jej wykonania za przestępstwo przeciwko wolności seksualnej i obyczajności, jeżeli pokrzywdzony był małoletnim poniżej lat 15.

Taka ingerencja w romską kulturę, tradycję czy obyczajowość, a już tym bardziej kara dla młodego Roma spotkała się z nieprzychylnym przyjęciem przez tę społeczność. Tak to właśnie siła czy może słabość prawa lub ustawodawcy (tu - nieumiejętność właściwej oceny oraz nieprzewidywalność konfliktów aksjologiczno-prawnych, odbiorcami których są wyłącznie adresaci norm), a nie wartość argumentu aksjologicznego przesądza o konflikcie oraz o karze niewinnego człowieka. Taki też jest byt przestępstw formalnych, uwikłanych w kontekst kulturowy w obecnym multikulturowym społeczeństwie, w którym prawo może dyskryminować inne subkultury (lub ich nie dyskryminować), będące częścią polskiego społeczeństwa. Jaka może być ocena moralna takiego prawodawcy? Czy jest to ustawowe łamanie praw tradycji (obyczaju) grup czy społeczności o odmiennej kulturze, które kultywując swoją tradycję, nie wyrządziły nikomu szkody i które też nie naraziły nikogo ani niczego na żadne niebezpieczeństwo w rozumieniu systemu prawnego? A jednak takie zachowanie spotkało się z sankcją karną (sic!).

Jak miałby zachować się prokurator czy sędzia, który byłby Romem, w takiej sprawie i jak miałby osądzić taki czyn? Pomijam oczywiście moralne podstawy takiego materialnego prawa, zwłaszcza jego arbitralności aksjologicznej, bo nie wymaga to chyba komentarza. Właśnie tu, ze względu na konflikt wewnętrznych wartości z obszarów moralności, tradycji, obyczaju, zwyczaju, religii, które głęboko zakorzenione są w świadomości takiej grupy, które są prymarną częścią jej porządku normatywnego i których stosowanie nikomu nic złego nie czyni - uwidacznia się ten konflikt sumienia decydenta

32 Przykład za: J. Zajadło, Prawo a idea równości: wszystkich równo czy wszystkich takjak równych?, [w:] tenże, Po co prawnikom filozofia prawa, Warszawa 2008, s. 135 i n. 
prawnego, który powinien być proceduralnie rozwiązany, by rzeczywiście decydent prawny mógł być wewnętrznie przekonany (zakładam, że z maksymalną bezstronnością). Mimo iż prokurator pełni inną funkcję, to i tak ostatni głos należy do sędziów, którzy czuwają nad prawidłowym przebiegiem całego postępowania.

Ci główni decydenci prawni mogliby (powinni) stosować prawo nie tylko w kontekście legalizmu (czy zasady rządów prawa), ale też - przede wszystkim - w kontekście zgodności aksjologicznej (różnych kultur, dla których dany czyn nie jest przestępstwem), która zawiera się w społecznym poczuciu sprawiedliwości i pluralizmie wartości. Rozważna decyzja prawna mogłaby przyczyniać się do większego równoważenia dystynkcji aksjologicznych będących coraz bardziej doniosłą częścią życia, a przez to i bardziej legitymować oceny prawne i stosowanie prawa, bo system prawny ma właśnie chronić i pomnażać wartości indywidualne i grupowe (społeczne), które uczynią funkcjonowanie państwa bardziej przyjaznym wobec tego antropocentrycznego pluralizmu wartości (oczywiście takich, które nie naruszają dóbr materialnych, osobowych i nieosobowych innych jednostek).

Społeczeństwa i ich władza polityczna, które organizując się, tworzą ponadregionalne czy ponadpaństwowe organizmy prawne, muszą siłą rzeczy uwzględnić te dyferencjacje aksjologiczno-prawne, by stwarzać możliwości rozwoju różnorodności kultur, by nie dyskryminować żadnej z nich, by ewentualnie prawo materialne czy proceduralne uwzględniało (lub szukało odpowiedniego konsensusu aksjologicznego) te dystynkcje kulturowe, tak aby stosowanie prawa umacniało więzi międzyludzkie, by motywowało do jego przestrzegania, by wartość społecznego poczucia sprawiedliwości wzrastała, na ile jest to możliwe. Czasy hegemonii państwa nad jednostką, jednej opcji partyjnej, promocji narzuconej (arbitralnej) aksjologii czy monokultury chyba już minęły? 


\section{Abstract}

By creating law, a legislator is guided by his own perception and understanding of legal values, which does not prejudge content-related power of particular legal solutions at all. Taking under consideration political and axiological changeability, concrete legal solutions disperse. Democracy only intensifies the conflict of values as far as law creation is concerned. However, applying of the law is based on changeable act and politics as well as differently understood legal values in the application of the law, which is proven by diversified jurisdiction or repealing judgements in appeal procedure.

The author questions rationality of constituting the law and its application when such axiological fluctuations occur. Whenever subject-object evaluation happens, also certain rationality is lost, which does not mean that such rationality is unattainable. Rationality should not be "the quantity" (voting) or "the power" of authorities (the last resort) but the quality of cause and effect relationship connected with normativity. The described traps of law application and ethical dilemmas in the present model of norm application prove the existing conflict of values which mainly decides about the ultimate legal decision. In such way, the essential value - justice - is lost. The author poses the question whether axiological accordance for example in court-litigant party relationship will not diminish the problem of value conflict. Those dilemmas have never been normalized by legislators. The author stipulates not to use the law through axiological "dissimilarity", which is, in fact, the main factor in legal decision. Considering the present level of legal and moral development are we able to offer better legal solutions in order to maximize the rule of impartiality and gain the best of justice? The answer seems obvious but do we have enough courage in democracy to defend unjudgment through opposition or axiological "dissimilarity", which also brings another unsaid partiality? 